\title{
Article \\ A Tribological and Ion Released Research of Ti-Materials for Medical Devices
}

\author{
Daniela Silva ${ }^{1, *}$, Camila Arcos ${ }^{1, *(1)}$, Cecilia Montero ${ }^{2}\left(\mathbb{D}\right.$, Carolina Guerra $^{1}$, Carola Martínez ${ }^{3} \mathbb{D}$, Xuejie Li $^{4}$, \\ Armelle Ringuedé ${ }^{4}$, Michel Cassir ${ }^{4}$, Kevin Ogle ${ }^{4}$, Danny Guzmán ${ }^{5}(0)$, Claudio Aguilar ${ }^{6}\left(\mathbb{D}\right.$, Maritza Páez ${ }^{7}(\mathbb{D}$ \\ and Mamié Sancy 8,9
}

check for updates

Citation: Silva, D.; Arcos, C.;

Montero, C.; Guerra, C.; Martínez, C.; Li, X.; Ringuedé, A.; Cassir, M.; Ogle, K.; Guzmán, D.; et al. A Tribological and Ion Released Research of Ti-Materials for Medical Devices. Materials 2022, 15, 131. https:// doi.org/10.3390/ma15010131

Academic Editors: Daniel Georgiev and Florin Miculescu

Received: 28 October 2021

Accepted: 15 December 2021

Published: 24 December 2021

Publisher's Note: MDPI stays neutral with regard to jurisdictional claims in published maps and institutional affiliations.

Copyright: (C) 2021 by the authors. Licensee MDPI, Basel, Switzerland. This article is an open access article distributed under the terms and conditions of the Creative Commons Attribution (CC BY) license (https:/ / creativecommons.org/licenses/by/ $4.0 /)$.
1 Departamento de Ingeniería Mecánica y Metalúrgica, Escuela de Ingeniería, Pontificia Universidad Católica de Chile, Santiago 7820436, Chile; caguerra2@uc.cl

2 Departamento de Ingeniería Metalúrgica, Facultad de Ingeniería, Universidad de Santiago, Santiago 9170022, Chile; marta.montero@usach.cl

3 Departamento de Ingeniería de Obras Civiles, Universidad de La Frontera, Temuco 4780000, Chile; carola.martinez@ufrontera.cl

4 CNRS, Institut de Recherche de Chimie de Paris, Chimie ParisTech, PSL University, 75005 Paris, France; xuejie.li@chimieparistech.psl.eu (X.L.); armelle.ringuede@chimie-paristech.fr (A.R.); michel.cassir@chimieparistech.psl.eu (M.C.); kevin.ogle@chimieparistech.psl.eu (K.O.)

5 Departamento de Ingeniería en Metalurgia, Universidad de Atacama, Copiapó 1530000, Chile; danny.guzman@uda.cl

6 Departamento de Ingeniería Metalúrgica y de Materiales, Universidad Técnica Federico Santa María, Valparaíso 2390123, Chile; claudio.aguilar@usm.cl

7 Departamento de Química de los Materiales, Facultad de Química y Biología, Universidad de Santiago de Chile, Santiago 9170022, Chile; maritza.paez@usach.cl

8 Escuela de Construcción Civil, Pontificia Universidad Católica de Chile, Santiago 7820436, Chile; mamiesancy@gmail.com

9 Centro de Investigación en Nanotecnologiía y Materiales Avanzados "CIEN-UC", Pontificia Universidad Católica de Chile, Santiago 7820436, Chile

* Correspondence: dpsilva6@uc.cl (D.S.); cearcos@uc.cl (C.A.)

Abstract: The increase in longevity worldwide has intensified the use of different types of prostheses for the human body, such as those used in dental work as well as in hip and knee replacements. Currently, Ti-6Al-4V is widely used as a joint implant due to its good mechanical properties and durability. However, studies have revealed that this alloy can release metal ions or particles harmful to human health. The mechanisms are not well understood yet and may involve wear and/or corrosion. Therefore, in this work, commercial pure titanium and a Ti-6Al-4V alloy were investigated before and after being exposed to a simulated biological fluid through tribological tests, surface analysis, and ionic dissolution characterization by ICP-AES. Before exposure, $\mathrm{X}$-ray diffraction and optical microscopy revealed equiaxed $\alpha$-Ti in both materials and $\beta$-Ti in Ti-6Al-4V. Scratch tests exhibited a lower coefficient of friction for Ti-6Al-4V alloy than commercially pure titanium. After exposure, $\mathrm{X}$-ray photoelectron spectroscopy and surface-enhanced Raman spectroscopy results showed an oxide film formed by $\mathrm{TiO}_{2}$, both in commercially pure titanium and in $\mathrm{Ti}-6 \mathrm{Al}-4 \mathrm{~V}$, and by $\mathrm{TiO}$ and $\mathrm{Al}_{2} \mathrm{O}_{3}$ associated with the presence of the alloys. Furthermore, inductively coupled plasma atomic emission spectroscopy revealed that aluminum was the main ion released for Ti-6Al-4V, giving negligible values for the other metal ions.

Keywords: Ti-6Al-4V; surface characterization; ion release; scratch test

\section{Introduction}

Commercially pure titanium (CP-Ti), and its alloys, have been extensively investigated due to their use in the manufacture of orthopedic devices. Their properties, such as low density, high specific resistance, and good corrosion resistance, make these materials attractive for that particular application [1,2]. Specifically, the Ti-6Al-4V alloy is used in 
dental and orthopedic implants [3,4]. However, the exposure of this alloy to biofluids has been shown to foster ion release [5,6], promoting harmful and undesirable effects for the human body [7], ranging from the induction of allergies to the promotion of the granuloma's formation and even carcinomas $[6,8]$. Concerning the harmful effects, genotoxicity was associated with vanadium release from in vitro studies up to peripheral neuropathy and even Alzheimer's disease [9-11]. Aluminum is also considered a neurotoxin, increasing the risk of degenerative diseases such as Alzheimer's [12-14]. Therefore, using these materials in biomedical applications require the guarantee of no potential adverse effects of released metal cations during their exposure to biofluids.

A method for quantifying ion release in situ is through atomic emission spectroelectrochemistry (AESEC), which has been successfully applied to monitor the ion release from metallic implants at laboratory scale [15-17]. In this sense, Luxin et al. [18] analyzed $\mathrm{Mg}^{2+}$ release from Ti-xMg $(\mathrm{x}=0.312,0.625,1.25$ and $2.5 \mathrm{wt} . \%)$ after $1,3,7,14$, and 28 days of immersion at $37^{\circ} \mathrm{C}$. The authors quantified ion release of all alloys, which exhibited similar behavior, and observed a quick release the first day followed by an increase in longer exposure times. Furthermore, the authors found that the cation release rate at each time depended on the $\mathrm{Mg}$ content; thus, the maximum release followed this trend: Ti-0.312 Mg < Ti-0.625 Mg < Ti-1.25 Mg < Ti-2.5 Mg. Guerra et al. [19] also used this technique to observe the ion release in a porous Ti-20Nb-11Ta-16Fe-1Mn after 30 days of exposure to simulated body fluid (SBF). No ion proceeding from the alloy was quantifiable by AESEC but inductively coupled plasma atomic emission spectrometry (ICP-AES) enabled detection of 1.9 and $4.8 \mathrm{ppb}$ of $\mathrm{Mn}$ and Fe, respectively, attributed to an increase in the thickness of the oxide layer during the exposure, improving passivation. Yan et al. [20] investigated the effect of $\mathrm{Zr}$ ion release for coated-Ti with $\mathrm{Zr}$ ion-implantation on osteogenesis. These authors found that more particles were released for longer ion implantation time, which was related to an increase in genes due to osteogenesis. On the other hand, Yamazoe et al. [21] determined that the release of Ti cations is related to microstructure, where the level of release decreased when the titanium grain size was small for titanium/dental alloy. $\mathrm{Hu}$ et al. [22] also observed that Ti cation release diminished with grain size decreased in $\mathrm{Ti}-45 \mathrm{Nb}$ when they compared a coarse-grained sample by casting with an ultrafine-grained (UFG) sample by high-pressure torsion. The authors explained that the UFG sample promotes a thicker surface passive layer with fewer defects.

Moreover, it has been reported that wear debris is a significant cause of periprosthetic osteolysis, which corresponds to a wear product [23]. Eger et al. [24] investigated the effect of surface treatment of the Ti disc on particle release associated with inflammation and osteolysis. In comparison with sandblasted/acid-etched material, sandblasted Ti showed a more significant amount of particle release, possibly due to a significant occurrence of protein-related inflammation and a critical bone loss for in vivo assays. Additionally, Zhang et al. [25] analyzed this using a natural analgesic and anti-inflammation drug (Bulleyaconitine or BLA) to prevent osteolysis induced by Ti particles. When Ti particles in contact with the bone were embedded with BLA, bone resorption decreased by suppressing osteoclast formation and stimulating osteoblast differentiation and mineralization. Therefore, the surface condition of Ti-6Al-4V plays an important role when estimating what phenomena an implant will undergo within the body.

Therefore, in this work, to better understand the corrosion and/or wear mechanisms of commercially pure titanium (CP-Ti) and Ti-6Al-4V, a comparison of both materials was carried out by using tribological, surface, and electrochemical analyses [26,27], studying mainly the surface damage.

\section{Materials and Methods}

\subsection{Samples}

$\mathrm{CP}-\mathrm{Ti}$ and commercial Ti-6Al-4V wt.\% were purchased (Chilexpo) as wrought samples having a $25 \mathrm{~mm}$ diameter, which were mechanized to achieve $8 \mathrm{~mm}$ and $6 \mathrm{~mm}$ diameter and height, respectively. For CP-Ti, the chemical composition was (in wt. \%): $0.02 \mathrm{C}, 0.015 \mathrm{H}$, 
$0.03 \mathrm{Fe}, 0.03 \mathrm{~N}, 0.25 \mathrm{O}$, and balance Ti. For Ti-6Al-4V, the chemical composition was (in wt.\%): $0.08 \mathrm{C}, 0.015 \mathrm{H}, 0.25 \mathrm{Fe}, 0.05 \mathrm{~N}, 0.20 \mathrm{O}, 5.5-6.75 \mathrm{Al}, 3.5-4.5 \mathrm{~V}$, and balance Ti. Both samples were mechanically polished using, first, SiC paper from 600 to 2400 grade, then, with a colloidal silica suspension of $0.05 \mu \mathrm{m}$. Later, the samples were cleaned with an ethanol solution in a sonicator bath for $10 \mathrm{~min}$.

\subsection{Structural and Microstructural Characterization}

X-ray diffraction (XRD) patterns of CP-Ti and Ti-6Al-4V samples were also collected with a Shimadzu XDR-6000 diffractometer with $\mathrm{Cu}-\mathrm{K} \alpha$ radiation (Shimadzu Corp., Tokyo, Japan), with an angular step of $0.02^{\circ}(2 \theta)$ and a time for a step of $6 \mathrm{~s}$. Furthermore, CP-Ti and Ti-6Al-4V samples were etched with Kroll's reagent for $20 \mathrm{~s}$ to observe the microstructure using an Olympus model-BX46M optical microscope (Olympus Corporation, Shinjuku-ku, Tokyo, Japan) for microstructural analysis.

\subsection{Tribological Characterization}

Scratch tests were performed using the single-pass. The coefficient of friction (COF) was estimated by applying $1 \mathrm{~N}$ and $5 \mathrm{~N}$ loads at room temperature and dry sliding conditions, with a tangential scratch speed of $2.5 \mathrm{~mm} \mathrm{~s}^{-1}$, a scratch length of $5 \mathrm{~mm}$, and in triplicate, as described previously by Martínez et al. [28]. A tip stylus with a Rockwell-C diamond cone with a $120^{\circ}$ opening angle and a $200 \mu \mathrm{m}$ spherical tip radius and a linear drive indenter (UMT2-Bruker) was used, and the wear track volume (DV) analysis was performed using a 3D-profilometer (CCI-MP-3D Taylor-Hobson). In this case, CP-Ti and Ti-6Al-4V samples were also observe using an Olympus model-BX46M optical microscope (Olympus Corporation, Shinjuku-ku, Tokyo, Japan).

\subsection{Exposure}

CP-Ti and Ti-6Al-4V samples were exposed to $50 \mathrm{~mL}$ of naturally aerated Hank's solution using a thermostatic bath operated at $37{ }^{\circ} \mathrm{C}$. Hank's solution contained (in g/L): $0.14 \mathrm{CaCl}_{2}, 0.40 \mathrm{KCl}, 8.00 \mathrm{NaCl}, 0.10 \mathrm{MgSO}_{4}, 0.06 \mathrm{KH}_{2} \mathrm{PO}_{4}, 0.05 \mathrm{NaHPO}_{4}$, and 1.00 glucose [29]. The exposure was performed in a static condition, and Hank's solution was refreshed partially after 7 days of exposure.

\subsection{Surface Analysis}

An X-ray photoelectron spectrometer FlexPS SPECS with an energy scale (XPS, SPECS Surface Nano Analysis GmbH Voltastrasse 5, Berlin, Germany) calibrated with the binding energy of advantageous hydrocarbons $(\mathrm{C}-\mathrm{C} / \mathrm{C}-\mathrm{H})$ in the $\mathrm{C} 1 \mathrm{~s}$ signal at $285.2 \mathrm{eV}$ was used. The fitting and decomposition of the curve were performed after removing the Shirley-type background. Before and after exposure, Raman spectra were collected using a Renishaw InVia confocal Raman microscope with WiRE software and a green laser (doubled Nd: YAG, $532 \mathrm{~nm}$ ) with 10\% laser power (Renishaw, New Mills, Wotton under Edge, UK). Raman measurements were performed with Leica objective $(\times 50, \mathrm{NA}=0.75)$. In this case, the exposure time of the laser was $1 \mathrm{~s}$, with 30-50 acquisitions and an estimated $0.87 \mu \mathrm{m}$ laser spot diameter. XPS and Raman after exposure were realized after 1 and 14 days, respectively. Morphological characterization was performed using a field emission-scanning electron microscope (FE-SEM, Quanta FEG 250, Thermo Fisher Scientific, Waltham, MA, USA) with secondary electrons. Additionally, chemical composition analysis of samples was carried out using an energy-dispersive spectrometer (EDS, Thermo Fisher Scientific, Waltham, MA, USA) that used a silicon drift detector (SDD, Thermo Fisher Scientific, Waltham, MA, USA), with an Octane Pro model with $10 \mathrm{~mm}^{2}$ detection area of $130 \mathrm{eV}$ resolution, and resolution stability over $90 \%$ up to 200 kcps (Thermo Fisher Scientific, Waltham, MA, USA).

\subsection{Ionic Dissolution Characterization}

Real-time dissolution analysis of CP-Ti and Ti-6Al-4V samples was performed using AESEC. This technique consisted of an electrochemical flow cell coupled to an inductively 
coupled plasma atomic emission spectrometer (ICP-AES) (Ultima 2C Horiba-Jobin Yvon, Palaiseau, France) for downstream elemental analysis. A three-electrode flow cell was used, which was constructed in-house, as desbribed by K. Ogle [30]. A saturated calomel electrode and platinum wire were employed as a reference and counter electrode, respectively. A flow rate of $2.86 \mathrm{~mL} \mathrm{~min}^{-1}$ was passed through the cell, and electrochemical (E, i) and spectroscopic emission data were collected with a time resolution of 1 data per second. The emission wavelengths used were $337.279 \mathrm{~nm}$ for Ti, $396.152 \mathrm{~nm}$ for $\mathrm{Al}$, and $311.071 \mathrm{~nm}$ for $\mathrm{V}$ and were calibrated by the standard methods using commercial standards of the elements in Hank's solution electrolyte. The detection limit (DL), in parts per billion (ppb) was 1.3 for $\mathrm{Ti}, 18$ for $\mathrm{Al}$, and 2.7 for $\mathrm{V}$. The detection limit was defined as $\mathrm{DL}=3 \mathrm{~s}$, where $\mathrm{s}$ is the standard deviation of the background signal of the blank solution. Elemental dissolution was monitored after 14 days of exposure at $37 \pm 1{ }^{\circ} \mathrm{C}$ during an electrochemical sequence an open circuit potential (EOC), followed by linear sweep voltammetry (LSV) at a scan rate of $0.25 \mathrm{mV} \mathrm{s}^{-1}$. After that, alternating EOC and overpotentials $(\eta)$ conditions were applied, and a chronoamperometry at $\eta=0.5 \mathrm{~V}$ and $\eta=1 \mathrm{~V}$ was also applied.

Additionally, the accumulated elemental dissolution was measured during the exposure described in Section 2.4 by removing a $20 \mathrm{~mL}$ aliquot of the exposed electrolyte after 7 and 14 days of exposure to Hank's solution and subjecting the aliquot to elemental analysis by ICP-AES (Ultima 2C Horiba-Jobin Yvon, Palaiseau, France). After extracting the aliquot, the immersed solution was completed with a fresh $20 \mathrm{~mL}$ solution.

\section{Results and Discussion}

\subsection{Structural and Microstructural Analysis}

Figure 1 shows the XRD patterns of $\mathrm{CP}-\mathrm{Ti}$ and Ti-6Al-4V samples before exposure. CP-Ti peaks correspond to hexagonal $\alpha$-Ti phase, while Ti-6Al-4V peaks are associated with $\alpha$-Ti and cubic $\beta$-Ti phases. These are the typical phases in the Ti-6Al-4V alloy heattreated with a low cooling rate [31,32]. It should be noticed that the presence of alloying elements modifies the microstructure from a pure $\alpha$-Ti phase to $(\alpha+\beta)$-Ti phases $[33,34]$. The principal difference is the appearance of the peaks in Ti-6Al-4V around $37.5^{\circ}, 57^{\circ}$, and $71^{\circ}$, possibly associated with the $\beta$-Ti phase due to the presence of $\beta$-Ti stabilizer, vanadium [35-37]. Additionally, the relative intensity of the peak at $38^{\circ}$, corresponding to the (1010) plane [38], is lower for Ti-6Al-4V than CP-Ti. This can be associated with a prismatic texture of Ti-6Al-4V, where a higher plastic deformation results in lower peak intensity [39-41]. This influence is also observed at $53^{\circ}, 63^{\circ}, 71^{\circ}$ and $77^{\circ}$, which can be related to heat treatment, as described by Beladi et al. [42].

Figure 2 shows the microstructure of $\mathrm{CP}-\mathrm{Ti}$ and Ti-6Al-4V before exposure. Figure $2 \mathrm{a}$ shows the CP-Ti microstructure with an equiaxial $\alpha$-Ti, as was previously reported by Amanov et al. [43], Gil et al. [44], and Greger [45]. It is possible that darker zones were generated by over-etching, as was proposed by G. Vander Voort [46]. A matrix characterizes Ti-6Al-4V microstructure with a phase homogeneously distributed, attributed to equiaxial $\alpha$-Ti and intergranular $\beta$-Ti (lighter and darker zones in Figure $2 b$ ), respectively, as reported by Çaha et al. [47] for commercial Ti-6Al-4V, and by Dabrowski [48] for rolled and annealed Ti-6Al-4V at low cooling rates.

\subsection{Tribological Characterization}

Figure 3 shows the COF of CP-Ti and Ti-6Al-4V at two applied loads, 1 and $5 \mathrm{~N}$. The $\mathrm{COF}$ increased during the scratch test for a load of $1 \mathrm{~N}$ (see Figure 3a), also revealing an oscillatory behavior for the CP-Ti sample that can be attributed to the susceptibility to the friction-induced instability, possibly due to the material roughness (not determined here). The COF amplitude variation is called the stick-slip effect $[49,50]$, which agrees with Amonov et al. [43], who suggested that this variation could be attributed to the localized fracture of the transfer layer and the interaction of the particles at the sliding interface. For $1 \mathrm{~N}$ load, the average values of COF were close to $0.63 \pm 0.11$ for CP-Ti and $0.65 \pm 0.09$ for Ti-6Al-4V. Instead, for $5 \mathrm{~N}$ load, the COF was $0.64 \pm 0.06$ for $\mathrm{CP}-\mathrm{Ti}$, being reduced 
to $0.46 \pm 0.04$ for Ti-6Al-4V. Therefore, the COF decreases in the Ti-6Al-4V sample when the applied load increases, agreeing with Gain [51] and Yazdi [52]. This reduction can be associated with the higher coverage of the tribolayer on the wear surface with higher normal loads, which decreases the adhesion between mating surfaces, as proposed by Yazdi et al. [52]. Li et al. [53] observed a decrease in the coefficient of friction at higher loads at a different sliding velocity in Ti-6Al-4V, which was related to an increase of the hardness with the load.

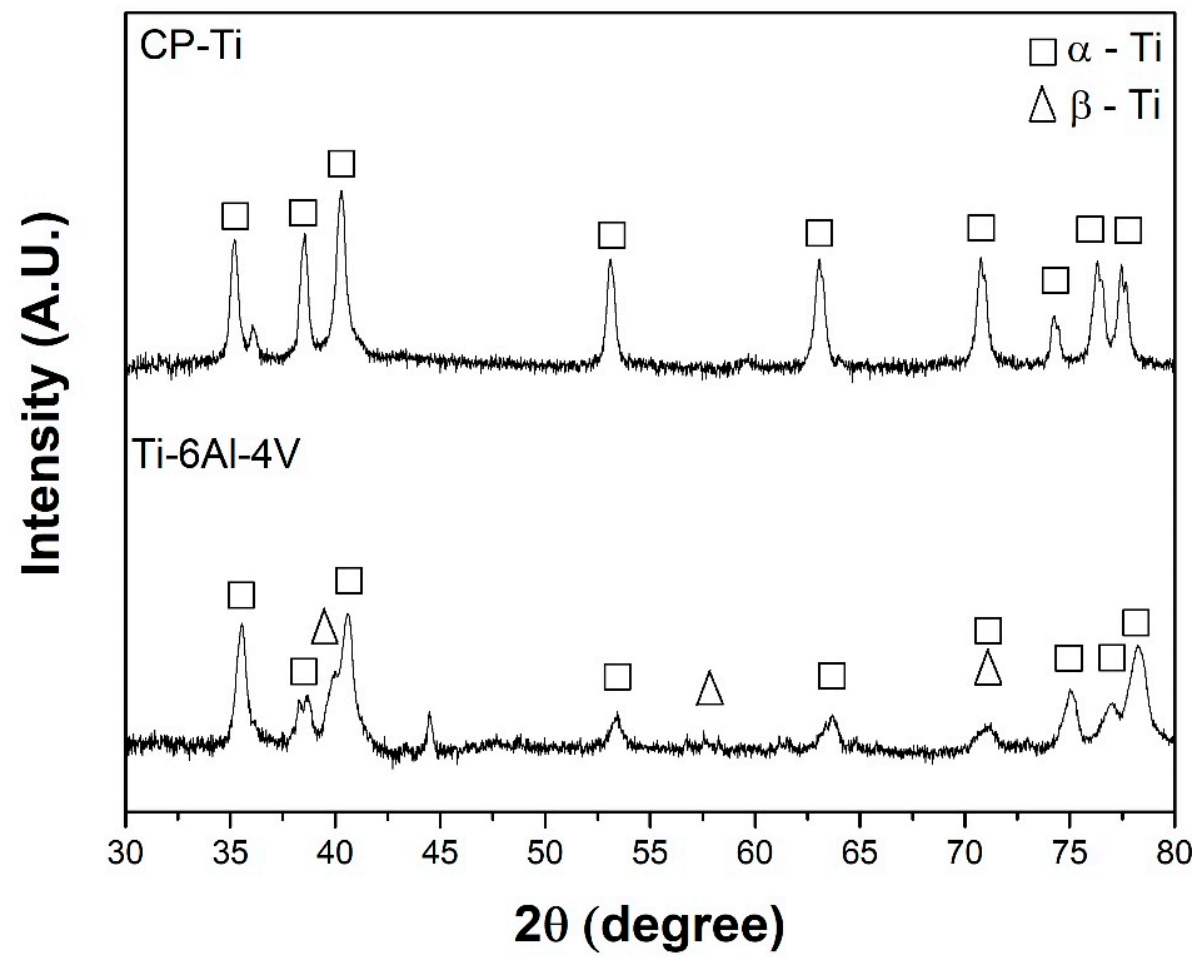

Figure 1. X-ray diffraction (XRD) patterns of CP-Ti and Ti-6Al-4V before exposure.
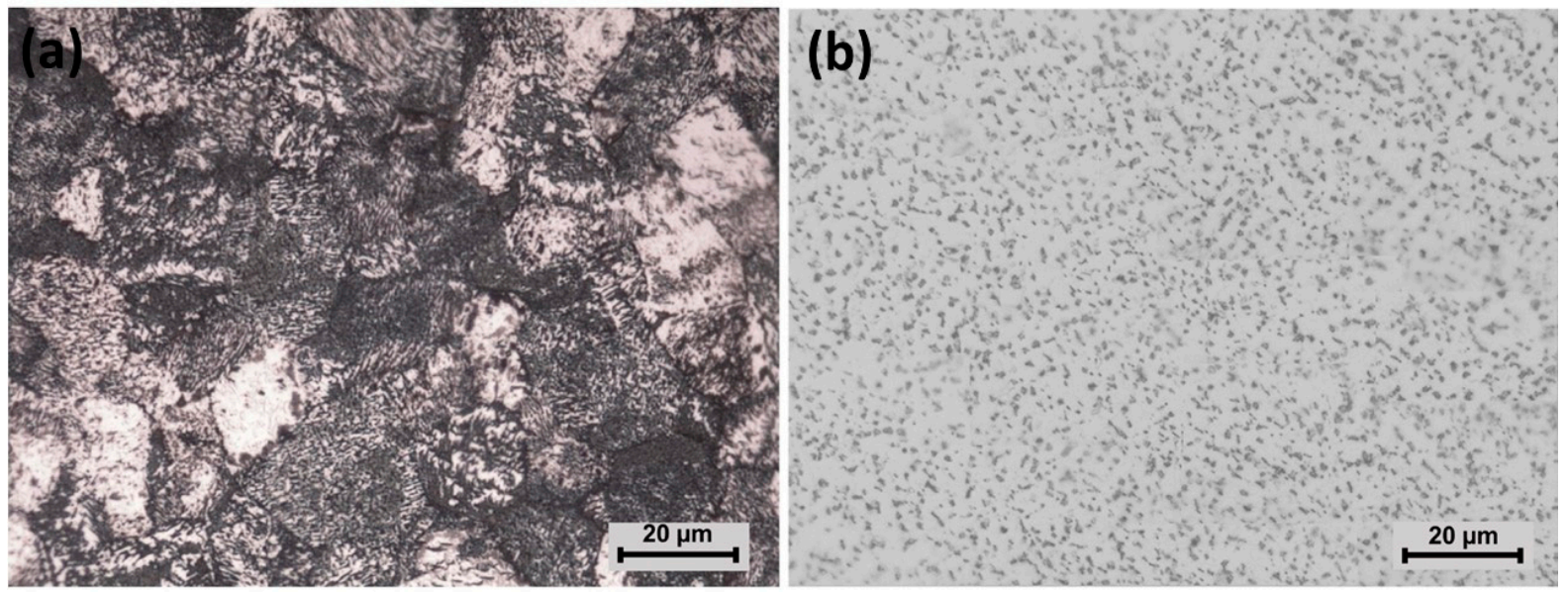

Figure 2. Optical images of (a) CP-Ti and (b) Ti-6Al-4V prior to exposure.

Figure 4 shows the indenter penetration depth for wear tracks of CP-Ti and Ti-6Al-4V samples. According to Vencl et al. [54], the scratch test by a single point is used to study the interaction that occurs between the abrasive particle (tip) and the surfaces to be studied (CP-Ti and Ti-6Al-4V), where the abrasive particle (tip) simulates wear. 

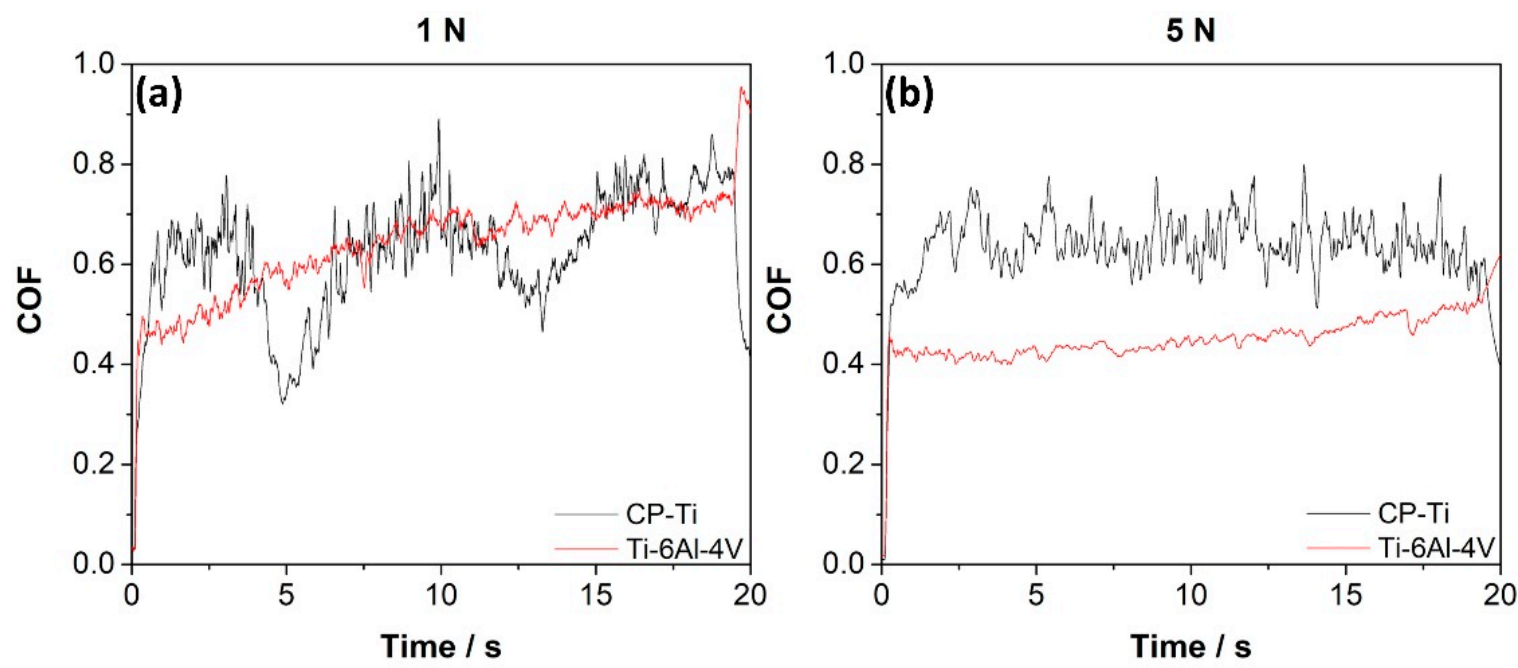

Figure 3. Coefficient of friction (COF) variation of the CP-Ti and Ti-6Al-4V surfaces under load of (a) $1 \mathrm{~N}$ and (b) $5 \mathrm{~N}$.
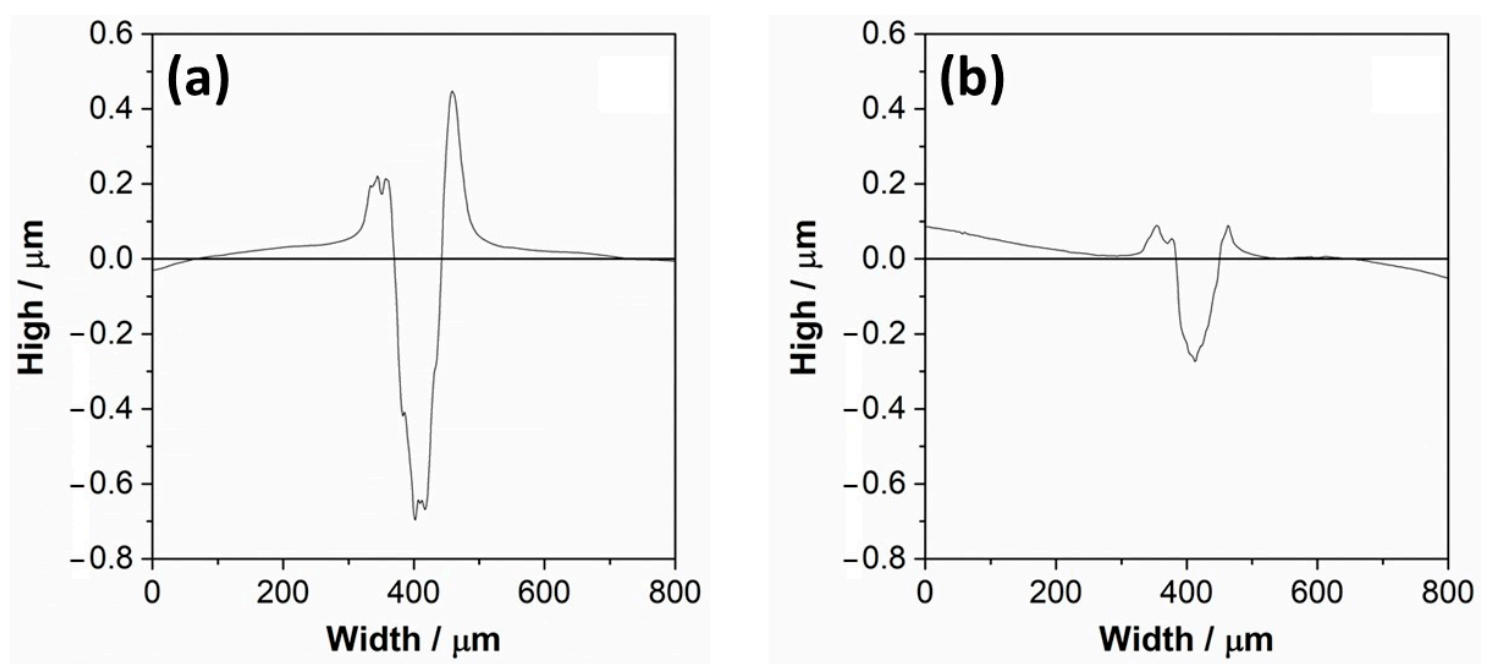

Figure 4. Cross-section profiles of scratches on the surface of (a) CP-Ti and (b) Ti-6Al-4V.

The grooved surface of the CP-Ti sample had a penetration value close to $-0.7 \mu \mathrm{m}$ of depth (see Figure 4a), while the profile of scratch of the Ti-6Al-4V sample had a penetration value relative to $-0.3 \mu \mathrm{m}$ of depth (see Figure $4 \mathrm{~b}$ ). This behavior has been attributed to the hardness difference, close to $146 \mathrm{HV}_{0.5}$ for $\mathrm{CP}-\mathrm{Ti}$ [43] and $350 \pm 5 \mathrm{HV}_{0.5}$ for Ti-6Al-4V [47] by solution hardening of $\mathrm{Al}$ in Ti-6Al-4V. The phases volume fraction also influences hardness, as was studied by Patil et al. [55], in Ti-6Al-4V with different thermal treatment, where hardness was reduced with an increase of alpha volume fraction. This is according to Archard's law, where a higher hardness is related to lower wear volume with a constant load [56]. On the other hand, the area of the groove surface of CP-Ti was near 51.1\%, and the pile-up area was $48.8 \%$. Therefore, $99.9 \%$ of the groove surface transferred to the pile-up, which means that $0.07 \%$ corresponded to a loss of material. In accordance with Rajendhran et al. [57], this could be due to the micro-ploughing mechanism, which represents the steady-state formation of a groove that has ridges on both sides formed by local plastic deformation without the formation of wear debris because the percentage of material loss is almost negligible. The area of the groove surface of Ti- $6 \mathrm{Al}-4 \mathrm{~V}$ was close to $71.8 \%$, and the pile-up area $27.9 \%$. Therefore, $38.9 \%$ of the groove surface transfer to the pile-up, which means that $61.1 \%$ corresponds to a loss of material. A dry sliding wear study made by Alam et al. [58] on Ti-6Al-4V showed a severe adhesion to the counter body, which could explain the significant amount of lost material. 
As reported by Rajendhran et al. [57], wear in terms of scratch width and depth are the possible means to measure the damage assessment. In most cases, the scratch width is estimated to control the wear. However, the width of the cross-section profile scratches is similar for the surface of CP-Ti and Ti-6Al-4V, which have values of $72.19 \mu \mathrm{m}$ and $66.82 \mu \mathrm{m}$. While the depth or volume loss is more important for the wear resistance application, therefore, the shallowest depth corresponds to the Ti-6Al-4V surface, with an approximate value of $-0.3 \mu \mathrm{m}$, which would correspond to a greater resistance to wear compared to the CP-Ti surface with a depth value close to $-0.7 \mu \mathrm{m}$.

Consequently, the values of groove surface penetration indicate that the plastic deformation of CP-Ti is higher than Ti-6Al-4V. Farokhazes et al. [59] studied the surface of Ti-6Al-4V under a nitrogen atmosphere. According to the profile, they performed the same scratch test in a single pass but with an applied force of $10 \mathrm{~N}$, giving a deformation of about $-2.5 \mu \mathrm{m}$. This value is almost 10 times greater than that reported in this survey with an applied force of $5 \mathrm{~N}$, despite the similar microstructure (equiaxial $\alpha$-Ti and intergranular $\beta-\mathrm{Ti})$. This difference could be due to nitrides on the Ti-6Al-4V surface subjected to a nitrogenous environment and the higher hardness (430 $\pm 8 \mathrm{HV})$ of Farokhazes's sample.

Figure 5 shows the wear tracks' morphology to determine the specimens' wear mechanism subjected to different loads on the CP-Ti and Ti-6Al-4V samples. As mentioned above, samples were tested with two different loads, $1 \mathrm{~N}$ (see Figure 5a,b) and $5 \mathrm{~N}$ (see Figure 5c,d). For $1 \mathrm{~N}$ load, the surface of CP-Ti exhibited a noticeable plastic deformation that generated the accumulated material in different areas (red circle), micro-cracking in the edges of the wear tracks (yellow circle), and debris (black arrow). However, the mechanism changed for $5 \mathrm{~N}$ possibly due to the more homogeneously drag of accumulated material on the surface but the noticeable plastic deformation (red circle) and micro-cracking stayed in the edges of the wear tracks (yellow circle), revealing delamination as a new mechanism (orange circle). This behavior of the surface is in agreement with the literature, which stipulated that the dry contact involves different wear mechanisms that emerge at the same time $[51,60,61]$. For example, Gain et al. [51] found a severe adhesion between Ti-alloys and its counterpart during the transfer of Ti-6Al-4V dry contact sliding. Also, Li et al. [60] reported grooves and cracks on the Ti-6Al-4V surface after wear. In this context, Yildiz et al. [61] proposed that the wear particles first appear due to abrasion in the surface of Ti-6Al-4V, and were added to the pin later, increasing the friction. Additionally, it should be noticed that after $1 \mathrm{~N}$ load was applied (Figure 5b), the surface of Ti-6Al-4V exhibits ploughing (white arrow) and, in some areas, delamination (orange circle), as shown in Figure 5b. Nevertheless, when the load increases to $5 \mathrm{~N}$, deep ploughing (pink arrow) and the mechanisms mentioned before were observed, as proposed by Gain et al. [51], who also reported severe abrasive wear.

\subsection{Surface Analysis}

Figure 6 shows the Ti-6Al-4V XPS survey spectra and high-resolution spectra of Ti 2p, $\mathrm{O} 1 \mathrm{~s}, \mathrm{C}$ 1s after 1 day of exposure to Hank's solution. This work used carbon as internal reference at 285.1 and $288.3 \mathrm{eV}$ for calibrating peak positions. The Ti $2 \mathrm{p}$ spectra revealed two doublets at $455.8 \mathrm{eV}$ and $464.3 \mathrm{eV}$ associated with $\mathrm{Ti}^{2+}$ and $\mathrm{Ti}^{4+}$, respectively [62-64]. Mendis et al. [65] analyzed the oxide film formed on Ti-xTa alloys ( $x=10,20,30,50,60$, and $75 \mathrm{wt} \%$.) after exposure to Hank's solution, also observing two doublets, but at $453.61 \mathrm{eV}$ for $\mathrm{TiO}$ and $458.54 \mathrm{eV}_{\text {for }} \mathrm{Ti}^{4+}$, which were related to metallic titanium and $\mathrm{TiO}_{2}$. In this case, the authors also observed signals at $284.8 \mathrm{eV}, 286.24 \mathrm{eV}$, and $288.8 \mathrm{eV}$ attributed to the presence of $\mathrm{C}-\mathrm{C} / \mathrm{C}-\mathrm{H}, \mathrm{C}-\mathrm{O}$, and $\mathrm{C}=\mathrm{O}$, possibly due to environmental contamination. $\mathrm{Xu}$ et al. [66] studied the oxide layer of Ti-6Al-4V and Ti-25Nb-10Ta-1Zr-0.2Fe after exposure to Ringer's solution at $37^{\circ} \mathrm{C}$, observing three doublets for $\mathrm{Ti}^{4+}(464.3 \mathrm{eV}), \mathrm{Ti}^{3+}(462.3 \mathrm{eV})$, and $\mathrm{Ti}^{2+}$ $(455.4 \mathrm{eV})$ that were related to $\mathrm{TiO}_{2}, \mathrm{Ti}_{2} \mathrm{O}_{3}$, and $\mathrm{TiO}$. Furthermore, the doublet areas were calculated, revealing that $\mathrm{TiO}_{2}$ was present with $78 \%, \mathrm{Ti}_{2} \mathrm{O}_{3}$ with $15 \%$, and $\mathrm{TiO}$ with $7 \%$. The same doublets were found at the Ti 2 p spectrum of Ti-25Nb-10Ta-1Zr-0.2Fe but slightly shifted. The relative contents calculated for each doublet indicated that $\mathrm{TiO}_{2}$ was close to $83 \%, \mathrm{Ti}_{2} \mathrm{O}_{3}$ was $13 \%$, and $\mathrm{TiO}$ was near $4 \%$. They agree with the relative contents calculated 
of Ti species in this work, where $\mathrm{TiO}_{2}$ had the most significant presence, showing $93.5 \%$ and $6.5 \%$ for TiO. Deconvolution of O 1s spectra revealed three contributions at $528.9 \mathrm{eV}$, $530.1 \mathrm{eV}$, and $532.1 \mathrm{eV}$ corresponding to $\mathrm{O}^{2-}$, Ti-O $[67,68]$ and $\mathrm{O}$ from absorbed water [69], respectively. Similar behavior was observed by Silva et al. [29] for a porous Ti-6Al-4V sample that was exposed to Hank's solution at $37^{\circ} \mathrm{C}$. The $\mathrm{O} 1 \mathrm{~s}$ spectrum revealed the presence of the $\mathrm{O}^{2-}$ signal at $529.9 \mathrm{eV}$, associated with $\mathrm{Al}_{2} \mathrm{O}_{3}$. The following signals were also found: Ti-O at $530.4 \mathrm{eV}, \mathrm{O}-\mathrm{H}$ at $531.7 \mathrm{eV}$ in $\mathrm{O} 1 \mathrm{~s}$, and $\mathrm{Ti}^{4+}$ at $464.8 \mathrm{eV}, \mathrm{Ti}^{3+}$ at $459.8 \mathrm{eV}$ and $\mathrm{Ti}^{2+}$ at $454.4 \mathrm{eV}$.
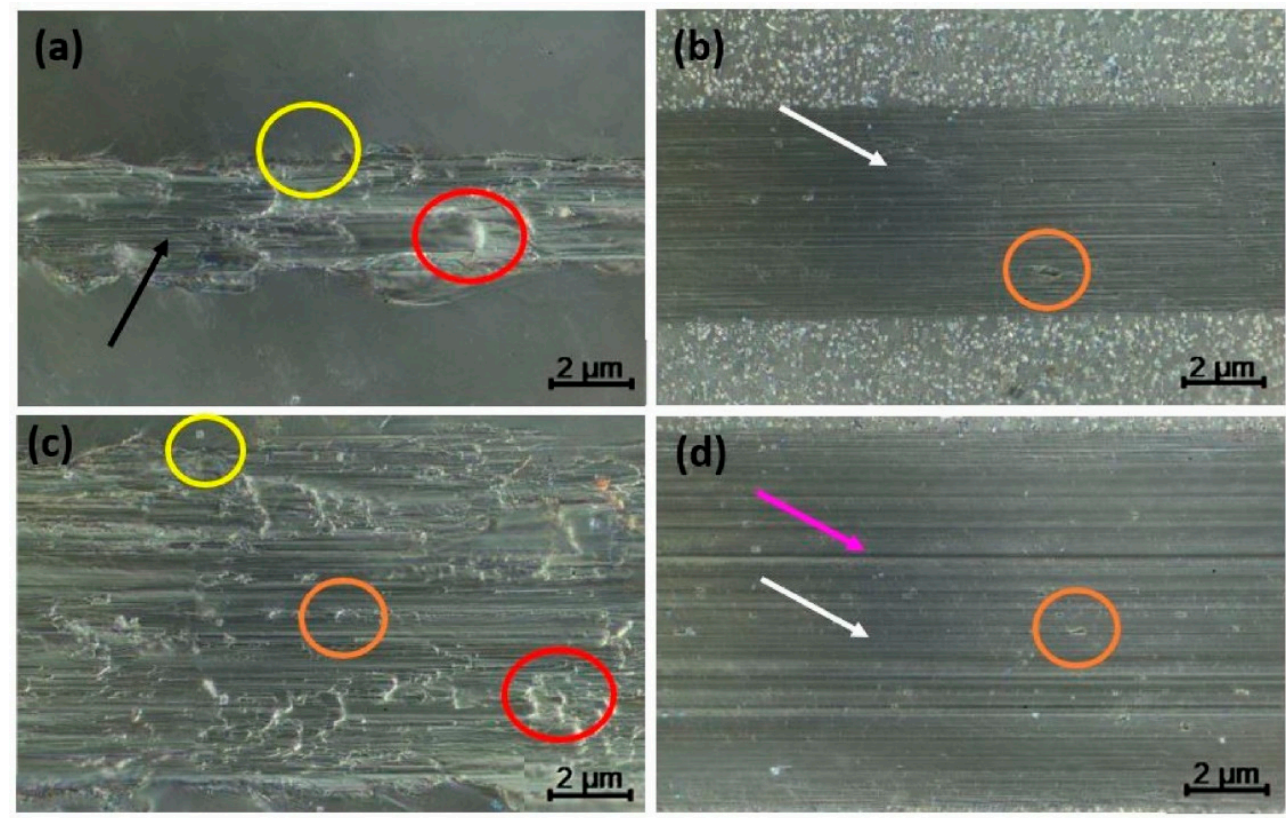

Figure 5. Optical micrographs of the wear track of CP-Ti $(\mathbf{a}, \mathbf{c})$ and Ti- $6 \mathrm{Al}-4 \mathrm{~V}(\mathbf{b}, \mathbf{d})$ under $1 \mathrm{~N}(\mathbf{a}, \mathbf{b})$ and $5 \mathrm{~N}(\mathbf{c}, \mathbf{d})$.

Figure 7 shows the Raman spectra of CP-Ti and Ti-6Al-4V before and after 14 days of exposure to Hank's solution, which revealed Raman bands in agreement with the active Raman modes of $\mathrm{TiO}_{2}$ that have been previously reported between $100-900 \mathrm{~cm}^{-1}[70,71]$. Before exposure, the spectra of CP-Ti revealed bands at $150.9 \mathrm{~cm}^{-1}, 224 \mathrm{~cm}^{-1}, 803.4 \mathrm{~cm}^{-1}$, while after exposure, the bands were slightly shifted at $146.6 \mathrm{~cm}^{-1}, 232.9 \mathrm{~cm}^{-1}$, and $797.7 \mathrm{~cm}^{-1}$. Ekoi et al. [72] studied the effect of a microwave plasma process on the CPTi disc to promote an oxide layer growing before exposure to an oxygen atmosphere. The authors registered the Raman bands at $143.2 \mathrm{~cm}^{-1}, 446.6 \mathrm{~cm}^{-1}, 609.8 \mathrm{~cm}^{-1}$, and $800.27 \mathrm{~cm}^{-1}$, which were related to $\mathrm{B}_{1 \mathrm{~g}}, \mathrm{E}_{\mathrm{g}}, \mathrm{A}_{1 \mathrm{~g}}$, and $\mathrm{B}_{2 \mathrm{~g}}$ Raman active modes. In this case, $\mathrm{B}_{1 \mathrm{~g}}$ was attributed to symmetric bending vibration, $\mathrm{E}_{\mathrm{g}}$ to symmetric stretching vibration, and $\mathrm{A}_{1 \mathrm{~g}}$ to anti-symmetric bending vibration of $\mathrm{O}-\mathrm{Ti}-\mathrm{O}[73,74]$. For Ti-6Al-4V, similar bands were observed at $152 \mathrm{~cm}^{-1}, 222.9 \mathrm{~cm}^{-1}, 798.9 \mathrm{~cm}^{-1}$ before exposure, and at $143.2 \mathrm{~cm}^{-1}$, $233.0 \mathrm{~cm}^{-1}$ and $802.3 \mathrm{~cm}^{-1}$ after exposure. Furthermore, Nouicer et al. [75] also exposed the Ti-6Al-4V to an SBF solution, observing that Raman bands were close to $150 \mathrm{~cm}^{-1}, 230 \mathrm{~cm}^{-1}$, and $800 \mathrm{~cm}^{-1}$, attributed to $\mathrm{TiO}_{2}$ (rutile). Shaikh et al. [76] studied the bioactivity and biocompatibility of Ti-6Al-4V after a surface modification by using a laser technique, which revealed Raman bands at $151 \mathrm{~cm}^{-1}, 217 \mathrm{~cm}^{-1}, 417 \mathrm{~cm}^{-1}$, and $610 \mathrm{~cm}^{-1}$ after modification that were associated mainly with $\mathrm{TiO}_{2}$ and $\mathrm{Ti}_{3} \mathrm{O}_{5}$, as oxide. Therefore, XPS and Raman analyses revealed that the oxide layer formed on the CP-Ti and Ti-6Al-4V was mainly formed by $\mathrm{TiO}_{2}$, with a minor contribution of $\mathrm{Al}_{2} \mathrm{O}_{3}$ for Ti-6Al-4V. 

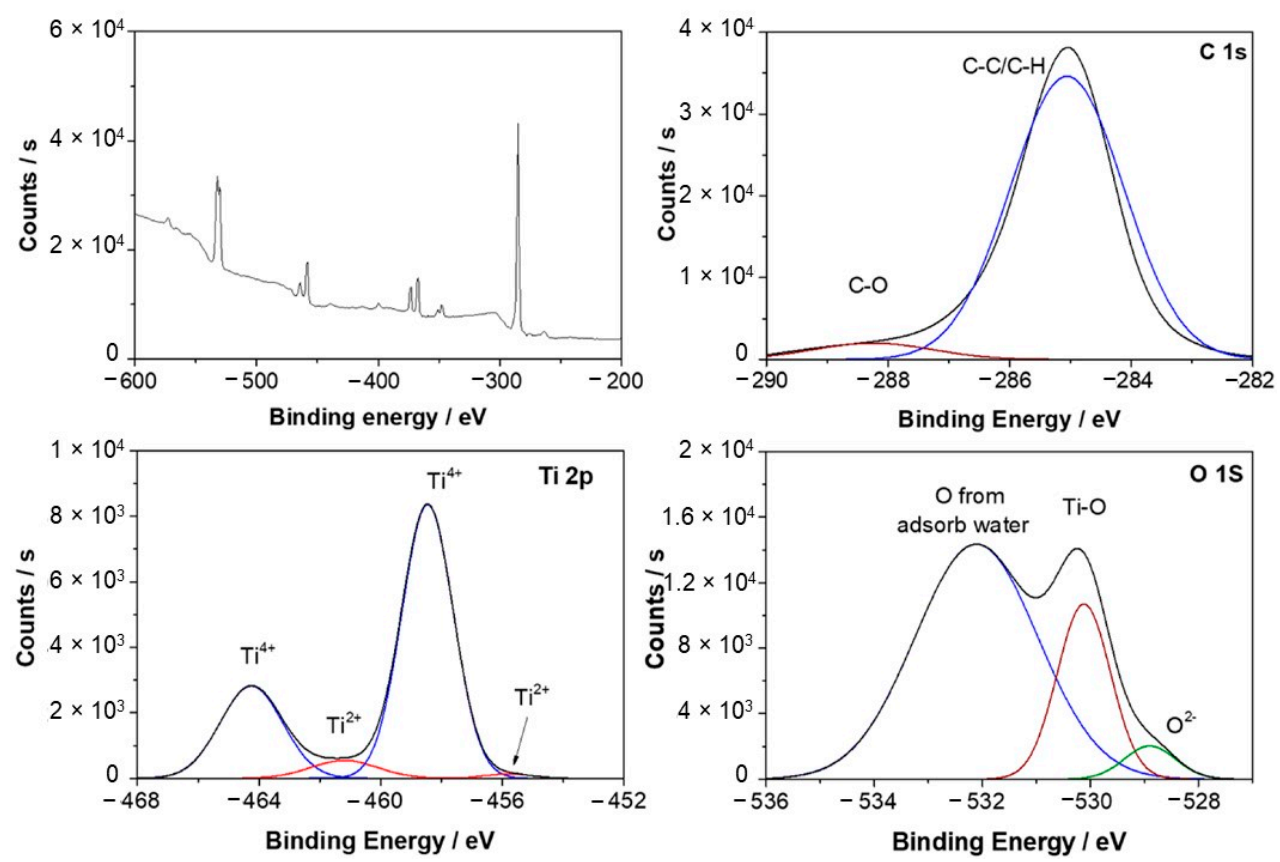

Figure 6. X-ray photoelectrom spectrometry (XPS) survey and C1 s, Ti 2p and O 1 s spectra of Ti-6Al-4V after 1-day exposure in simulated body fluid.
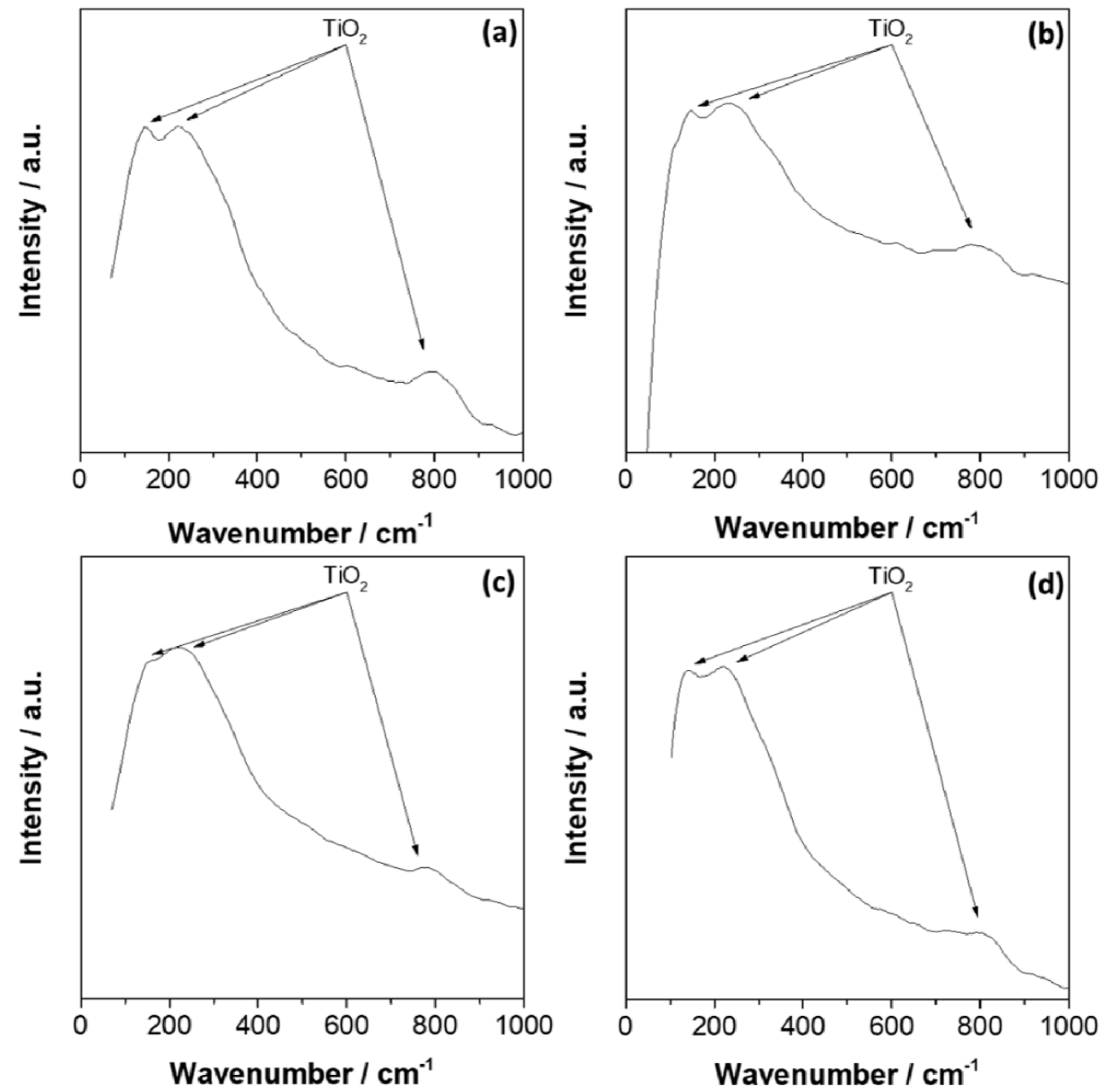

Figure 7. Raman spectra of pure Ti $(\mathbf{a}, \mathbf{b})$ and Ti-6Al-4V (c,d) before $(\mathbf{a}, \mathbf{c})$ and after $(\mathbf{b}, \mathbf{d}) 14$ days of exposure to Hank's solution. 
Figure 8 shows the FE-SEM images for CP-Ti and Ti-6Al-4V before and after 14 days of exposure and under an overpotential condition. Before exposure, no differences were observed between the samples, without superficial imperfections. However, after 14 days of exposure, the CP-Ti sample did reveal a higher surface damage than that of the Ti-6Al-4V sample, agreeing with the higher corrosion rate for CP-Ti than Ti alloys, as reported by Gurappa [77]. In fact, in both images, it is possible to observe scratch lines resulting from the polishing process, which can be associated with a more stable and harder passive oxide layer over Ti-6Al-4V. According to Lee et al. [78,79], in commercial Ti and Ti-6Al-4V specimens, a distinct structural change is not observed on the surface even after samples being soaked in Hank's solution for 30 days.
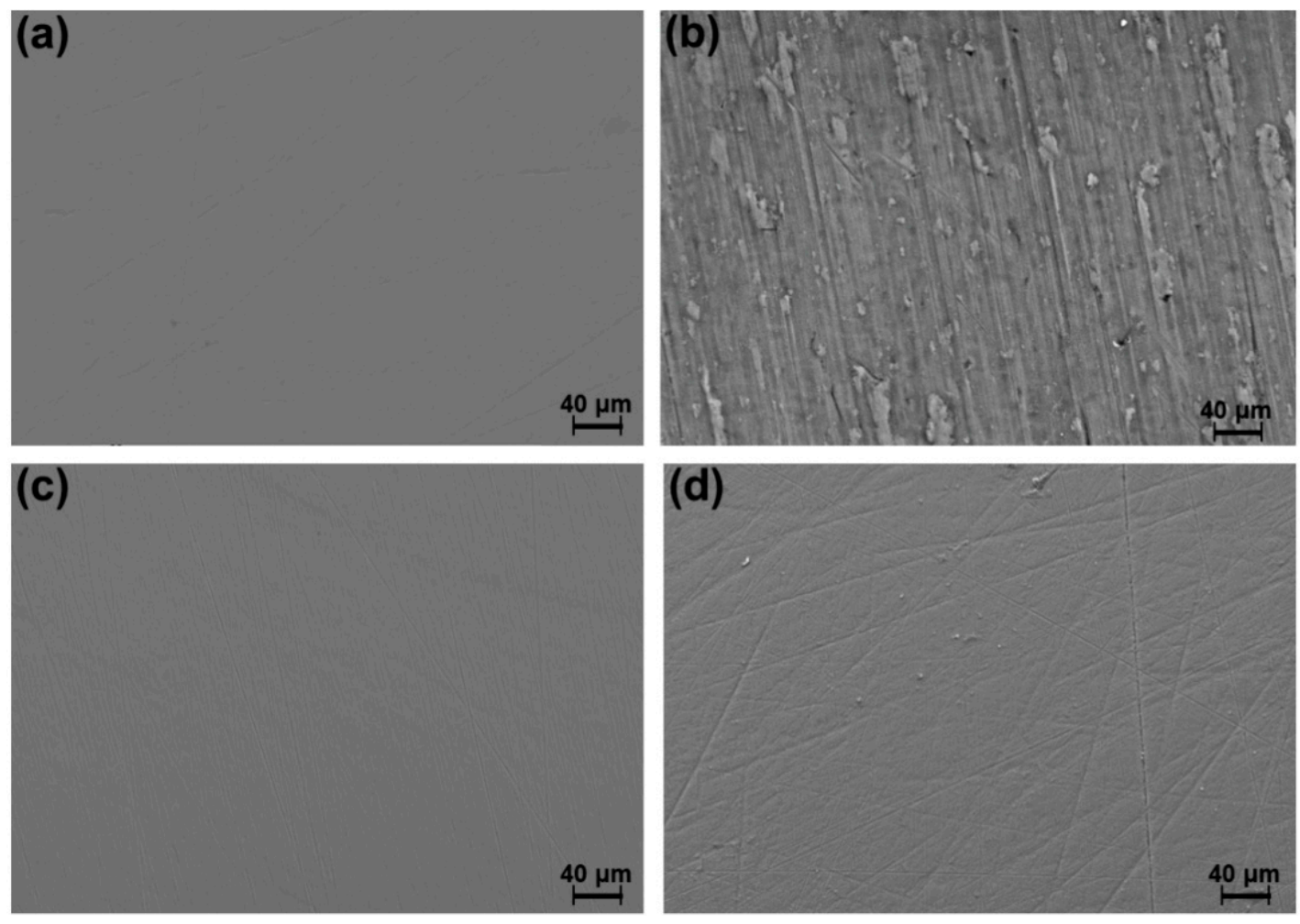

Figure 8. Scanning electron microscope (SEM) images of $(\mathbf{a}, \mathbf{b}) \mathrm{CP}-\mathrm{Ti}(\mathbf{c}, \mathbf{d}) \mathrm{Ti}-6 \mathrm{Al}-4 \mathrm{~V}(\mathbf{a}, \mathbf{c})$ prior to and (b,d) after 14 days of exposure to Hank's solution.

\subsection{Real-Time Elemental Dissolution Analysis}

Figure 9 shows the AESEC results of CP-Ti and Ti-6Al-4V after 14 days of exposure to Hank's solution at $37^{\circ} \mathrm{C}$. Notice that the electrochemical data and the simultaneous atomic emission measurement for the respective elements can be seen in Figure 9. The emission intensities $\left(\mathrm{I}_{\lambda}\right)$ as a function of time show no elemental dissolution during the sequence of electrochemical experiments. The detection limits are shown on the right-hand side of the respective curves.

It should be noted that $\mathrm{I}_{\lambda}$ was corrected for background drift by normalizing with the emission intensity at $371.029 \mathrm{~nm}$, associated with the element $\mathrm{Y}$, which is not present in our system. Failure to make this correction could falsely attribute slow changes in the emission intensity background to changes in the elemental dissolution rate. The horizontal dashed lines represent the separation of $3 \mathrm{~s}$, which is commonly used to define the detection limit for a given element and wavelength. The value of the detection limit expressed as an equivalent current is also given on the right. All the signals remain within the $3 \mathrm{~s}$ limit indicating that no measurable dissolution was observed. For CP-Ti, the electrical current remained lower than the detection limit of $\mathrm{Ti}$, expressed as an equivalent current, throughout the experiment except for the $+1 \mathrm{~V}$ potentiostatic experiment. The measurement 
of ionic dissolution would not be expected for these experiments under any circumstance. However, for the $+1 \mathrm{~V}$ potentiostatic experiment, the electrical current is more than one order of magnitude above the detection limit. The absence of detectable ionic dissolution during this step suggests that it makes a negligible contribution during the anodic oxidation of the material. The Ti-6Al-4V also showed no detectable ionic dissolution even though the electrical current was above the detection limit of Ti for each of the three dynamic experiments performed. The dissolution of the CP-Ti and Ti-based alloy was investigated for longer times by removing a $20 \mathrm{~mL}$ aliquot of the electrolyte during the exposure described in Section 2.4, after 7 and 14 days. The accumulated concentration of Ti, V, and $\mathrm{Al}$ as determined by ICP-AES, as shown in Table 1 . Ti and $\mathrm{V}$ were consistently below the detection limit (DL). For Ti-6Al-4V, however, a slight dissolution of $\mathrm{Al}$ was detected, rising to about $5.37 \mu \mathrm{g} \cdot \mathrm{cm}^{-2}$ to $6.96 \mu \mathrm{g} \cdot \mathrm{cm}^{-2}$ after 7 days to 14 days.

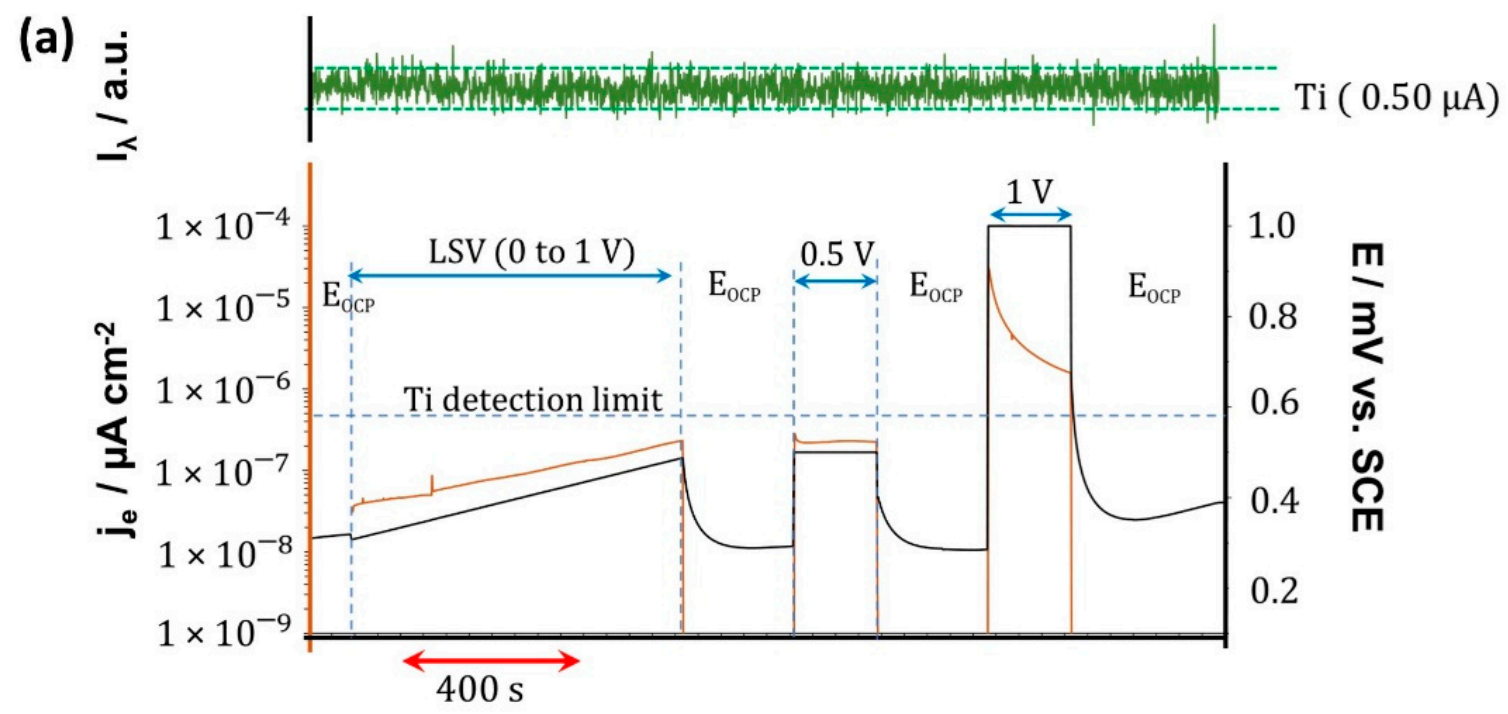

Time / s

(b)
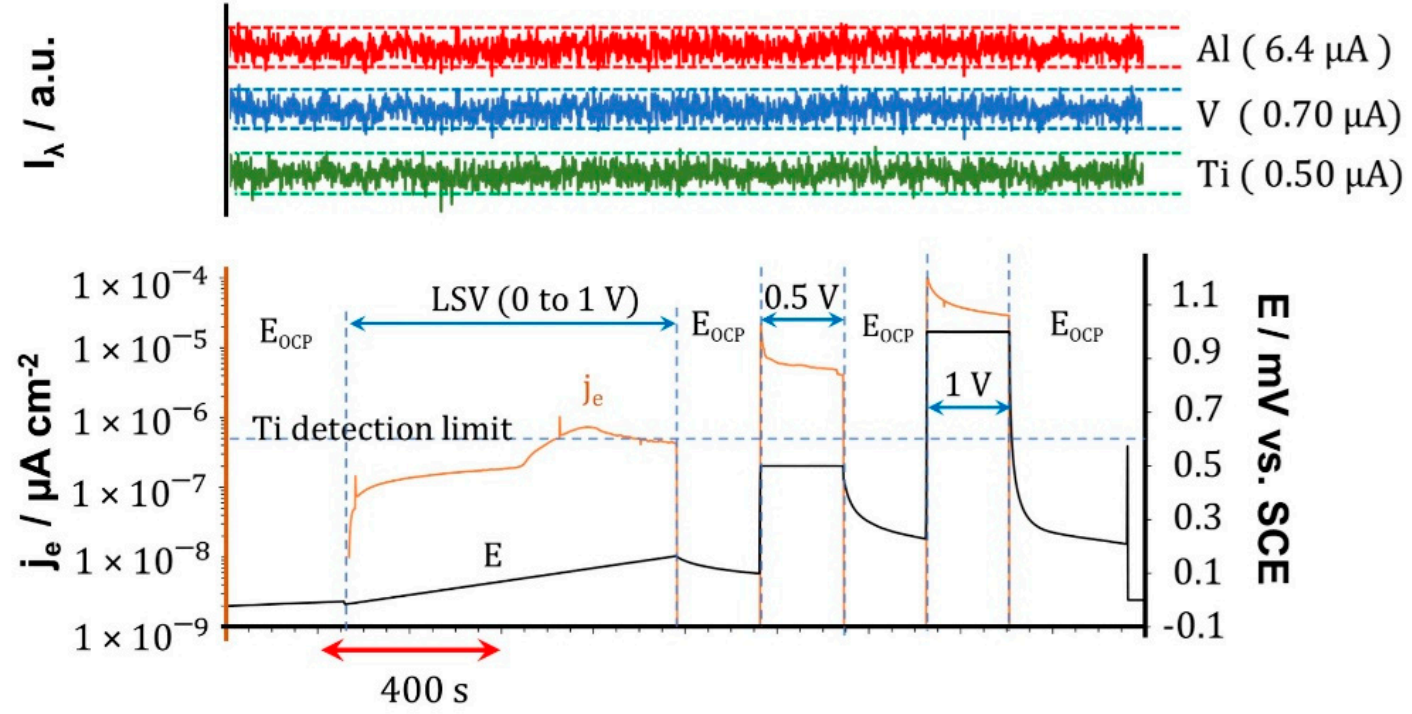

Time / s

Figure 9. Atomic emission spectroelectrochemistry (AESEC) results of (a) Ti and (b) Ti-6Al-4V after 14 days of exposure to Hank's solution. 
Table 1. Accumulated elemental dissolution measured for CP-Ti and Ti-6Al-4V samples after 7 and 14 days of exposure to Hank's solution.

\begin{tabular}{|c|c|c|c|c|}
\hline \multirow{2}{*}{ ICP-AES } & \multicolumn{4}{|c|}{ Accumulated Mass per Area $/ \mu \mathrm{g} \cdot \mathrm{cm}^{-2}$} \\
\hline & CP-Ti & & $-6 \mathrm{Al}-4$ & \\
\hline Time of Exposure/days & $\mathrm{Ti}$ & $\mathrm{Ti}$ & Al & $\mathbf{V}$ \\
\hline 7 & $<\mathrm{DL}$ & $<\mathrm{DL}$ & 5.37 & $<\mathrm{DL}$ \\
\hline 14 & $<\mathrm{DL}$ & $<\mathrm{DL}$ & 6.96 & $<\mathrm{DL}$ \\
\hline
\end{tabular}

Similar behavior was reported by Guerra et al. [19], who studied the porous alloy $\mathrm{Ti}-\mathrm{Nb}-\mathrm{Ta}-\mathrm{Fe}-\mathrm{Mn}$ after 30 days immersed in Ringer's solution at $37^{\circ} \mathrm{C}$. These authors also failed to detect release even after applying $\eta=+1 \mathrm{~V}$ against $\mathrm{SCE}$, which was associated with the formation and stability of the oxide formed and possibly, with good passivity, stable even at high overpotentials. According to the Raman analysis, the oxide film for both samples was composed mainly of $\mathrm{TiO}_{2}$ as rutile, which is a thermodynamically stable oxide [80] in standard conditions. It should also be noticed that the rutile exhibits a low Gibbs energy-free formation $[81,82]$ that should be stable even after applying a $\eta=+1 \mathrm{~V}$. Table 1 also shows ICP-AES results of CP-Ti, which exhibited a concentration of Ti under the DL for all exposure times.

On the other hand, Ti-6Al-4V alloy revealed a release in $\mathrm{Al}$ ion after 7 days of exposure, increasing after 14 days. A similar result was previously reported by Prodana et al. [83]. The authors reported ion release of all alloying elements, including $\mathrm{Al}$, for shorter exposure times and decreased ion releases after 14 days. This phenomenon is expected because the $\alpha$-Ti phase is rich in $\mathrm{Al}$, preferably dissolved [84-86]. In this context, Chen et al. [83] investigated Ti-6Al-4V exposed to simulated acidic solutions ( $\mathrm{pH} 3$ and 5), observing a preferential dissolution of the $\alpha$-Ti over $\beta$-Ti by the optical surface profiler technique. It should also be mentioned that XPS (see Figure 6) revealed peaks related to $\mathrm{Al}_{2} \mathrm{O}_{3}$, indicating that $\mathrm{Al}$ can also be part of the passive film.

Moreover, it has been observed that the alloys can suffer significant changes during the earlier stages, as was described by Silva et al. [29], who studied the Ti-6Al-4V exposed to Hank's solution for 21 days. Wang et al. [87] detected elemental Ti dissolution from $\mathrm{CP}-\mathrm{Ti}$ under open circuit and polarization conditions in a similar electrolyte (minimum equivalent media, or MEM), determining that the reactivity enhances with the addition of $0.1 \%$ albumin and $0.1 \% \mathrm{H}_{2} \mathrm{O}_{2}$. Time-resolved ICP mass spectrometry showed the equivalent faradaic dissolution rate reached approximately $4 \mu \mathrm{A} \mathrm{cm} \mathrm{cm}^{-2}$ when the electrical current was $\approx 8 \mu \mathrm{A} \mathrm{cm}^{-2}$, during a polarization using a similar electrochemical flow cell. It means a $50 \%$ faradaic yield of dissolution, demonstrating the aggressiveness of the modified electrolyte.

\section{Conclusions}

The characterization of the wear and corrosion behavior of CP-Ti and Ti-Al-V, using $\mathrm{COF}$ measurements and quantification of released ions, revealed that Ti-Al-V has a better performance. This was evidenced by the wear properties, where a lower COF and lower wear residue than CP-Ti were observed. This is partly explained by the RAMAN, XPS, and $\mathrm{XRD}$ results, which revealed that the oxide film formed on Ti-Al-V surface is composed mainly by $\mathrm{TiO}_{2}$ and $\mathrm{Al}_{2} \mathrm{O}_{3}$. However, the structural analysis revealed that alloy is composed of $\beta$-Ti and $\alpha$-Ti phases, which have a better mechanical respond than $\alpha$-Ti that is present in CP-Ti.

On the other hand, the quantification of released ions showed that Ti-Al-V exposed to Hank's solution has a robust barrier against corrosion, observing a low activity of released ions compared to CP-Ti. This is related to the passive oxide film formed on the surface, as verified by Raman and XPS, which protects the material from hasty dissolution. In fact, ICP-AES demonstrates that when an anodic overpotential was applied to promote the anodic reaction, Ti-Al-V showed low quantification of released ions for Ti and $\mathrm{V}$, being slightly higher for $\mathrm{Al}$. 


\begin{abstract}
Author Contributions: Conceptualization, D.S., C.A. (Camila Arcos), A.R., M.C., K.O., D.G. and M.S.; methodology, D.S., C.A. (Camila Arcos) and M.S.; validation, D.S., C.A. (Camila Arcos), C.M. (Cecilia Montero), C.G., X.L., D.G. and C.M. (Carola Martínez); formal analysis, D.S., C.A. (Camila Arcos) and C.G.; investigation, D.S., C.A. (Camila Arcos), C.M. (Cecilia Montero), C.G., X.L., D.G. and C.M. (Carola Martínez); resources, C.A. (Claudio Aguilar), A.R., M.C., K.O., D.G. and M.S.; data curation, D.S., C.A. (Camila Arcos), C.M. (Cecilia Montero), C.G., X.L., D.G. and C.M. (Carola Martínez); writing—original draft preparation, D.S., C.A. (Camila Arcos), C.G. and M.S.; writingreview and editing, D.S., C.A. (Camila Arcos), M.C., K.O., M.P. and M.S.; visualization, D.S. and C.A. (Camila Arcos); supervision, D.S., C.A. (Camila Arcos) and M.S.; project administration, M.S.; funding acquisition, M.P. and M.S. All authors have read and agreed to the published version of the manuscript.
\end{abstract}

Funding: This research was funded by ANID through FONDECYT (Grants 1160604 and 1180843), ANID-FONDEQUIP (Grant 170087), ECOS-ANID (Grant 170033), and Programa de Incentivo a la Iniciación Científica (PIIC). Additionally, Cecilia Montero thanks the University of Santiago for the Research Support Grant.

Institutional Review Board Statement: Not applicable.

Informed Consent Statement: Not applicable.

Data Availability Statement: The raw/processed data required to reproduce these findings cannot be shared at this time due to technical or time limitations.

Conflicts of Interest: The authors declare no conflict of interest. The funders had no role in the design of the study; in the collection, analyses, or interpretation of data; in the writing of the manuscript, or in the decision to publish the results.

\title{
References
}

1. Ke, Z.; Yi, C.; Zhang, L.; He, Z.; Tan, J.; Jiang, Y. Characterization of a new Ti-13Nb-13Zr-10Cu alloy with enhanced antibacterial activity for biomedical applications. Mater. Lett. 2019, 253, 335-338. [CrossRef]

2. Chen, Q.; Thouas, G.A. Metallic implant biomaterials. Mater. Sci. Eng. R Rep. 2015, 87, 1-57. [CrossRef]

3. Toptan, F.; Alves, A.C.; Carvalho, Ó.; Bartolomeu, F.; Pinto, A.M.P.; Silva, F.; Miranda, G. Corrosion and tribocorrosion behaviour of Ti6Al4V produced by selective laser melting and hot pressing in comparison with the commercial alloy. J. Mater. Process. Technol. 2019, 266, 239-245. [CrossRef]

4. Chávez, J.; Jimenez, O.; Olmos, L.; Farias, I.; Flores-Jimenez, M.; Suárez-Martínez, R.; Cabezas-Villa, J.L.; Lemus-Ruiz, J. Tribocorrosion behavior of Ti64-xTa alloys fabricated through powder metallurgy. Mater. Lett. 2020, 128590. [CrossRef]

5. Pechancova, R.; Pluháček, T.; Gallo, J.; Milde, D. Study of chromium species release from metal implants in blood and joint effusion: Utilization of HPLC-ICP-MS. Talanta 2018, 185, 370-377. [CrossRef] [PubMed]

6. Matusiewicz, H. Potential release of in vivo trace metals from metallic medical implants in the human body: From ions to nanoparticles-A systematic analytical review. Acta Biomater. 2014, 10, 2379-2403. [CrossRef]

7. Mellado-Valero, A.; Muñoz, A.I.; Pina, V.G.; Sola-Ruiz, M.F. Electrochemical behaviour and galvanic effects of titanium implants coupled to metallic suprastructures in artificial saliva. Materials 2018, 11, 171. [CrossRef]

8. Hanawa, T. Metal ion release from metal implants. Mater. Sci. Eng. C. 2004, 24, 745-752. [CrossRef]

9. Costa, B.C.; Tokuhara, C.K.; Rocha, L.A.; Oliveira, R.C.; Lisboa-Filho, P.N.; Costa Pessoa, J. Vanadium ionic species from degradation of Ti-6Al-4V metallic implants: In vitro cytotoxicity and speciation evaluation. Mater. Sci. Eng. C 2019, 96, 730-739. [CrossRef]

10. Lin, C.-W.; Ju, C.-P.; Chern Lin, J.-H. A comparison of the fatigue behavior of cast Ti-7.5Mo with c.p. titanium, Ti-6Al-4V and Ti-13Nb-13Zr alloys. Biomaterials 2005, 26, 2899-2907. [CrossRef]

11. Gomes, C.C.; Moreira, L.M.; Santos, V.J.S.V.; Ramos, A.S.; Lyon, J.P.; Soares, C.P.; Santos, F.V. Assessment of the genetic risks of a metallic alloy used in medical implants. Genet. Mol. Biol. 2011, 34, 116-121. [CrossRef]

12. Ahmed, G.A.; Khalil, S.K.H.; El hotaby, W.; Abbas, L.; Sherif, H.H.A.; Abdel-Rahman, E.A.; Saber, S.H.; Hassan, M.; Hassan, M.H.; Ali, S.S. ATR-IR and EPR spectroscopy for detecting the alterations in cortical synaptosomes induced by aluminium stress. Spectrochim. Acta Part A Mol. Biomol. Spectrosc. 2020, 228, 117535. [CrossRef]

13. Kawahara, M.; Kato-Negishi, M. Link between aluminum and the pathogenesis of Alzheimer's disease: The integration of the aluminum and amyloid cascade hypotheses. Int. J. Alzheimers. Dis. 2011, 2011, 276393. [CrossRef]

14. Kumar, V.; Gill, K.D. Oxidative stress and mitochondrial dysfunction in aluminium neurotoxicity and its amelioration: A review. Neurotoxicology 2014, 41, 154-166. [CrossRef]

15. Yan, Y.; Zhou, P.; Gharbi, O.; Zeng, Z.; Chen, X.; Volovitch, P.; Ogle, K.; Birbilis, N. Investigating ion release using inline ICP during in situ scratch testing of an Mg-Li(-Al-Y-Zr) alloy. Electrochem. Commun. 2019, 99, 46-50. [CrossRef] 
16. Hutchison, M.J.; Zhou, P.; Ogle, K.; Scully, J.R. Enhanced Electrochemical Cu Release from Commercial Cu-Sn Alloys: Fate of the Alloying Elements in Artificial Perspiration. Electrochim. Acta 2017, 241, 73-88. [CrossRef]

17. Vu, T.N.; Volovitch, P.; Ogle, K. The effect of $\mathrm{pH}$ on the selective dissolution of $\mathrm{Zn}$ and $\mathrm{Al}$ from $\mathrm{Zn}-\mathrm{Al}$ coatings on steel. Corros. Sci. 2013, 67, 42-49. [CrossRef]

18. Liang, L.; Huang, Q.; Wu, H.; Ouyang, Z.; Liu, T.; He, H.; Xiao, J.; Lei, G.; Zhou, K. Stimulation of in vitro and in vivo osteogenesis by Ti-Mg alloys with the sustained-release function of magnesium ions. Colloids Surf. B Biointerfaces 2021, 197. [CrossRef]

19. Guerra, C.; Sancy, M.; Walczak, M.; Martínez, C.; Ringuedé, A.; Cassir, M.; Han, J.; Ogle, K.; de Melo, H.G.; Salinas, V.; et al. Effect of added porosity on a novel porous Ti-Nb-Ta-Fe-Mn alloy exposed to simulated body fluid. Mater. Sci. Eng. C 2020, 111. [CrossRef] [PubMed]

20. Yan, B.; Tan, J.; Wang, D.; Qiu, J.; Liu, X. Surface alloyed Ti-Zr layer constructed on titanium by Zr ion implantation for improving physicochemical and osteogenic properties. Prog. Nat. Sci. Mater. Int. 2020, 30, 635-641. [CrossRef]

21. Yamazoe, M. Study of corrosion of combinations of titanium/Ti-6Al-4V implants and dental alloys. Dent. Mater. J. 2010, 29, 542-553. [CrossRef]

22. Hu, N.; Xie, L.; Liao, Q.; Gao, A.; Zheng, Y.; Pan, H.; Tong, L.; Yang, D.; Gao, N.; Starink, M.J.; et al. A more defective substrate leads to a less defective passive layer: Enhancing the mechanical strength, corrosion resistance and anti-inflammatory response of the low-modulus Ti-45Nb alloy by grain refinement. Acta Biomater. 2021, 126, 524-536. [CrossRef] [PubMed]

23. Ciapetti, G. Biology of implant wear. In Wear of Orthopaedic Implants and Artificial Joints; Woodhead Publishing Series in Biomaterials: Bologna, Italy, 2012; pp. 27-55. [CrossRef]

24. Eger, M.; Sterer, N.; Liron, T.; Kohavi, D.; Gabet, Y. Scaling of titanium implants entrains inflammation-induced osteolysis. Sci. Rep. 2017, 7, 39612. [CrossRef] [PubMed]

25. Zhang, L.; Feng, M.; Li, Z.; Zhu, M.; Fan, Y.; Chu, B.; Yuan, C.; Chen, L.; Lv, H.; Hong, Z.; et al. Bulleyaconitine A prevents Ti particle-induced osteolysis via suppressing NF- $\mathrm{kB}$ signal pathway during osteoclastogenesis and osteoblastogenesis. J. Cell. Physiol. 2018, 233, 7067-7079. [CrossRef] [PubMed]

26. Reports and Data. Titanium-Based Alloys Market Share, Trends-Industry Analysis, 2028. 2019. Available online: https: / / www.reportsanddata.com/report-detail/titanium-based-alloys-market (accessed on 26 October 2021).

27. Mordor Intelligence Titanium Alloy Market-2021-26-Industry Share, Size, Growth-Mordor Intelligence. 2020. Available online: https:/ / www.mordorintelligence.com/industry-reports/titanium-alloy-market (accessed on 26 October 2021).

28. Martínez, C.; Briones, F.; Araya, N.; Aguilar, C.; Machado, I.; Guerra, C.; Medina, A.; Sancy, M. Influence of the synthesis technique on tribological behavior of a Ti-6Al-4V alloy. Mater. Lett. 2020, 281, 4-7. [CrossRef]

29. Silva, D.; Guerra, C.; Muñoz, H.; Aguilar, C.; Walter, M.; Azocar, M.; Muñoz, L.; Gürbüz, E.; Ringuedé, A.; Cassir, M.; et al. The effect of Staphylococcus aureus on the electrochemical behavior of porous Ti-6Al-4V alloy. Bioelectrochemistry 2020, 136, 107622. [CrossRef] [PubMed]

30. Ogle, K. Atomic Emission Spectroelectrochemistry: Real-Time Rate Measurements of Dissolution, Corrosion, and Passivation. Corrosion 2019, 75, 1398-1419. [CrossRef]

31. Liu, S.; Shin, Y.C. Additive manufacturing of $\mathrm{Ti}_{6} \mathrm{Al}_{4} \mathrm{~V}$ alloy: A review. Mater. Des. 2019, 164, 8-12. [CrossRef]

32. ASM International. Titanium: Physical Metallurgy, Processing and Applications; ASM International: Geauga County, OH, USA, 2015; ISBN 9781627080798. [CrossRef]

33. Mindivan, F.; Mindivan, H.; Darcan, C. Electroless Ni-B Coating of Pure Titanium Surface for Enhanced Tribocorrosion Performance in Artificial Saliva and Antibacterial Activity. Tribol. Ind. 2017, 39, 270-276. [CrossRef]

34. Lee, K.; Choe, H.C.; Ko, Y.M.; Brentley, W.A. Nanotubular Structure Formation on Ti-6Al-4V and Ti-Ta Alloy Surfaces by Electrochemical Methods. Korean J. Met. Mater. 2012, 50, 164-170. [CrossRef]

35. Li, H.; Jia, D.; Yang, Z.; Liao, X.; Jin, H.; Cai, D.; Zhou, Y. Effect of heat treatment on microstructure evolution and mechanical properties of selective laser melted Ti-6Al-4V and TiB/Ti-6Al-4V composite: A comparative study. Mater. Sci. Eng. A 2021, 801, 140415. [CrossRef]

36. Fan, W.; Tan, H.; Zhang, F.; Feng, Z.; Wang, Y.; Zhang, L.C.; Lin, X.; Huang, W. Overcoming the limitation of in-situ microstructural control in laser additive manufactured Ti-6Al-4V alloy to enhanced mechanical performance by integration of synchronous induction heating. J. Mater. Sci. Technol. 2021, 94, 32-46. [CrossRef]

37. Yan, Q.; Chen, B.; Cao, L.; Liu, K.Y.; Li, S.; Jia, L.; Kondoh, K.; Li, J.S. Improved mechanical properties in titanium matrix composites reinforced with quasi-continuously networked graphene nanosheets and in-situ formed carbides. J. Mater. Sci. Technol. 2022, 96, 85-93. [CrossRef]

38. Dumontet, N.; Connétable, D.; Malard, B.; Viguier, B. Elastic properties of the $\alpha^{\prime}$ martensitic phase in the Ti-6Al-4V alloy obtained by additive manufacturing. Scr. Mater. 2019, 167, 115-119. [CrossRef]

39. Lütjering, G.; Williams, J.C. Titanium; Engineering Materials and Processes Book Series; Springer: Berlin, Germany, 2007; p. 341, ISBN 978-3-540-71397-5.

40. Wang, S.; Ma, Z.; Liao, Z.; Song, J.; Yang, K.; Liu, W. Study on improved tribological properties by alloying copper to CP-Ti and Ti-6Al-4V alloy. Mater. Sci. Eng. C 2015, 57, 123-132. [CrossRef] [PubMed]

41. Wang, C.; Yu, D.; Niu, Z.; Zhou, W.; Chen, G.; Li, Z.; Fu, X. The role of pyramidal $<\mathrm{c}+\mathrm{a}>$ dislocations in the grain refinement mechanism in Ti-6Al-4V alloy processed by severe plastic deformation. Acta Mater. 2020, 200, 101-115. [CrossRef] 
42. Beladi, H.; Chao, Q.; Rohrer, G.S. Variant selection and intervariant crystallographic planes distribution in martensite in a Ti-6Al-4V alloy. Acta Mater. 2014, 80, 478-489. [CrossRef]

43. Amanov, A.; Cho, I.S.; Kim, D.E.; Pyun, Y.S. Fretting wear and friction reduction of CP titanium and Ti-6Al-4V alloy by ultrasonic nanocrystalline surface modification. Surf. Coat. Technol. 2012, 207, 135-142. [CrossRef]

44. Javier Gil, F.; Planell, J.A.; Padrós, A.; Aparicio, C. The effect of shot blasting and heat treatment on the fatigue behavior of titanium for dental implant applications. Dent. Mater. 2007, 23, 486-491. [CrossRef]

45. Greger, M.; Kander, L.; Snasel, V.; Cerny, M. Microstructure evolution of pure titanium during ECAP. Mater. Des. 2011, 18, 97-104

46. Vander Voort, G. Metallographic Preparation of Titanium and its Alloys. In Proceedings of the Ninth World Concerence on Titanium, Central Research Institute of Structural Materials (CRISM) "Prometey", Saint-Petersburg, Russia, 7-11 June 1999.

47. Çaha, I.; Alves, A.C.; Chirico, C.; Tsipas, S.A.; Rodrigues, I.R.; Pinto, A.M.P.; Grandini, C.R.; Rocha, L.A.; Gordo, E.; Toptan, F. Interactions between wear and corrosion on cast and sintered Ti- $12 \mathrm{Nb}$ alloy in comparison with the commercial Ti-6Al-4V alloy. Corros. Sci. 2020, 176, 108925. [CrossRef]

48. Dabrowski, J.R. The Kinetics of Phase Transformations during Continuous Cooling of Ti6Al4V Alloy from the Diphase alfa + beta Range. Arch. Metall. Mater. 2011, 56, 5-9. [CrossRef]

49. Sherif, H.A.; Kossa, S.S. Relationship between normal and tangential contact stiffness of nominally flat surfaces. Wear 1991, 151, 49-62. [CrossRef]

50. Lee, S.M.; Shin, M.W.; Lee, W.K.; Jang, H. The correlation between contact stiffness and stick-slip of brake friction materials. Wear 2013, 302, 1414-1420. [CrossRef]

51. Gain, A.K.; Zhang, L.; Lim, S. Tribological behavior of Ti-6Al-4V alloy: Subsurface structure, damage mechanism and mechanical properties. Wear 2021, 464-465, 203551. [CrossRef]

52. Yazdi, R.; Ghasemi, H.M.; Abedini, M.; Monshi, M. Interplay between mechanical wear and electrochemical corrosion during tribocorrosion of oxygen diffusion layer on Ti-6Al-4V in PBS solution. Appl. Surf. Sci. 2020, 518, 146048. [CrossRef]

53. Li, X.X.; Zhou, Y.; Ji, X.L.; Li, Y.X.; Wang, S.Q. Effects of sliding velocity on tribo-oxides and wear behavior of Ti-6Al-4V alloy. Tribol. Int. 2015, 91, 228-234. [CrossRef]

54. Vencl, A.; Manić, N.; Popovic, V.; Mrdak, M. Possibility of the abrasive wear resistance determination with scratch tester. Tribol. Lett. 2010, 37, 591-604. [CrossRef]

55. Patil, S.; Kekade, S.; Phapale, K.; Jadhav, S.; Powar, A.; Supare, A.; Singh, R. Effect of $\alpha$ and $\beta$ Phase Volume Fraction on Machining Characteristics of Titanium Alloy Ti6Al4V. Procedia Manuf. 2016, 6, 63-70. [CrossRef]

56. Hutchings, I.M. Tribology: Friction and Wear of Engineering Materials; Butterworth-Heinemann: Oxford, UK, 1992; Volume 13, ISBN 9780081009109. [CrossRef]

57. Rajendhran, N.; De Baets, P.; Huang, S.; Vleugels, J.; Sukumaran, J. Single-point scratch testing for understanding particle engagement in abrasion of multiphase materials. Wear 2021, 476, 203689. [CrossRef]

58. Alam, M.O.; Haseeb, A.S.M.A. Response of Ti-6Al-4V and Ti-24Al-11Nb alloys to dry sliding wear against hardened steel. Tribol. Int. 2002, 35, 357-362. [CrossRef]

59. Farokhzadeh, K.; Qian, J.; Edrisy, A. Effect of SPD surface layer on plasma nitriding of Ti-6Al-4V alloy. Mater. Sci. Eng. A 2014, 589, 199-208. [CrossRef]

60. Li, S.J.; Yang, R.; Li, S.; Hao, Y.L.; Cui, Y.Y.; Niinomi, M.; Guo, Z.X. Wear characteristics of Ti-Nb-Ta-Zr and Ti-6Al-4V alloys for biomedical applications. Wear 2004, 257, 869-876. [CrossRef]

61. Yildiz, F.; Yetim, A.F.; Alsaran, A.; Efeoglu, I. Wear and corrosion behaviour of various surface treated medical grade titanium alloy in bio-simulated environment. Wear 2009, 267, 695-701. [CrossRef]

62. Zhang, H.; Man, C.; Wang, L.; Dong, C.; Wang, L.; Kong, D.; Wang, X. Different corrosion behaviors between $\alpha$ and $\beta$ phases of $\mathrm{Ti}_{6} \mathrm{Al}_{4} \mathrm{~V}$ in fluoride-containing solutions: Influence of alloying element Al. Corros. Sci. 2020, 169, 108605. [CrossRef]

63. Hasan, J.; Li, H.; Tian, G.; Qin, C. Fabrication of $\mathrm{Cr}_{2} \mathrm{~S}_{3}-\mathrm{GO}-\mathrm{TiO}_{2}$ composite with high visible-light-driven photocatalytic activity on degradation of organic dyes. Chem. Phys. 2020, 539, 110950. [CrossRef]

64. Xu, W.; Lu, X.; Tian, J.; Huang, C.; Chen, M.; Yan, Y.; Wang, L.; Qu, X.; Wen, C. Microstructure, wear resistance, and corrosion performance of Ti35Zr28Nb alloy fabricated by powder metallurgy for orthopedic applications. J. Mater. Sci. Technol. 2020, 41, 191-198. [CrossRef]

65. Mendis, S.; Xu, W.; Tang, H.P.; Jones, L.A.; Liang, D.; Thompson, R.; Choong, P.; Brandt, M.; Qian, M. Characteristics of oxide films on Ti-(10-75)Ta alloys and their corrosion performance in an aerated Hank's balanced salt solution. Appl. Surf. Sci. 2020 506, 145013. [CrossRef]

66. Xu, Y.F.; Xiao, Y.F.; Yi, D.Q.; Liu, H.Q.; Wu, L.; Wen, J. Corrosion behavior of Ti-Nb-Ta-Zr-Fe alloy for biomedical applications in Ringer's solution. Trans. Nonferrous Met. Soc. China 2015, 25, 2556-2563. [CrossRef]

67. Luo, Y.; Jiang, Y.; Zhu, J.; Tu, J.; Jiao, S. Surface treatment functionalization of sodium hydroxide onto 3D printed porous Ti6Al4V for improved biological activities and osteogenic potencies. J. Mater. Res. Technol. 2020, 9, 13661-13670. [CrossRef]

68. El Mel, A.A.; Angleraud, B.; Gautron, E.; Granier, A.; Tessier, P.Y. XPS study of the surface composition modification of nc-TiC/C nanocomposite films under in situ argon ion bombardment. Thin Solid Films 2011, 519, 3982-3985. [CrossRef]

69. Zhang, Y.; Li, J.; Xu, H.; Feng, L.; Zhang, T. Dynamic evolution of oxide film on selective laser melted Ti-6Al-4V alloy. J. Alloys Compd. 2020, 849, 156622. [CrossRef] 
70. Turek, A.M.; Wachs, I.E.; Hirt, A.M. Physical and chemical characterization of surface vanadium oxide supported on titania: Influence of the titania phase (anatase, rutile, brookite and B) Goutam. Appl. Catal. A Gen. 1992, 91, 27-42. [CrossRef]

71. Lukacevic, I.; Gupta, S.K.; Jha, P.K.; Kirin, D. Lattice dynamics and Raman spectrum of rutile $\mathrm{TiO}_{2}$ : The role of soft phonon modes in pressure induced phase transition. Mater. Chem. Phys. 2012, 137, 282-289. [CrossRef]

72. Ekoi, E.J.; Stallard, C.; Reid, I.; Dowling, D.P. Tailoring oxide-layer formation on titanium substrates using microwave plasma treatments. Surf. Coat. Technol. 2017, 325, 299-307. [CrossRef]

73. Yan, J.; Wu, G.; Guan, N.; Li, L.; Lib, Z.; Cao, X. Understanding the effect of surface/bulk defects on the photocatalytic activity of $\mathrm{TiO}_{2}$ : Anatase versus rutile. Phys. Chem. Chem. Phys. 2013, 15, 10978-10988. [CrossRef] [PubMed]

74. Zhang, Y.; Harris, C.X.; Wallenmeyer, P.; Murowchick, J.; Chen, X. Asymmetric Lattice Vibrational Characteristics of Rutile TiO 2 as Revealed by Laser Power Dependent Raman Spectroscopy. J. Phys. Chem. 2013, 117, 24015-24022. [CrossRef]

75. Nouicer, E.; Benlahreche, F.Z.; Nouicer, A. Spectroscopic characterization of titanium alloy surface in a biological medium. Acta Phys. Pol. A 2017, 131, 28-31. [CrossRef]

76. Shaikh, S.; Kedia, S.; Majumdar, A.G.; Subramanian, M.; Sinha, S. In vitro bioactivity and biocompatibility of femtosecond laser-modified Ti6Al4V alloy. Appl. Phys. A Mater. Sci. Process. 2018, 124, 821. [CrossRef]

77. Gurappa, I. Characterization of different materials for corrosion resistance under simulated body fluid conditions. Mater. Charact. 2002, 49, 73-79. [CrossRef]

78. Lee, M.H. Biocompatibility of a modified metallic surface of pure Ti and Ti-6Al-4V alloy with the connective tissue of mouse. Met. Mater. 2000, 6, 373-379. [CrossRef]

79. Lee, M.H.; Yoon, D.J.; Won, D.H.; Bae, T.S.; Watari, F. Biocompatibility of surface treated pure titanium and titanium alloy byin vivo andin vitro test. Met. Mater. Int. 2003, 9, 35-42. [CrossRef]

80. Hanaor, D.A.H.; Sorrell, C.C. Review of the anatase to rutile phase transformation. J. Mater. Sci. 2011, 46, 855-874. [CrossRef]

81. Ma, K.; Zhang, R.; Sun, J.; Liu, C. Oxidation Mechanism of Biomedical Titanium Alloy Surface and Experiment. Int. J. Corros. 2020, 2020, 1678615. [CrossRef]

82. Chen, C.C. Phase Equilibria at Ti-Al Interface Under Low Oxygen Pressure. Atlas J. Mater. Sci. 2014, 1, 1-11. [CrossRef]

83. Prodana, M.; Caposi, M.; Iordachescu, D. Ions release from Ti implant alloys in simulated bioliquids. In Proceedings of the 14th Nordic-Baltic Conference on Biomedical Engineering and Medical Physics, Riga, Latvia, 16-20 June 2008; Volume 20, pp. 60-63. [CrossRef]

84. Zhao, P.; Song, Y.; Dong, K.; Shan, D.; Han, E.-H. Corrosion behavior of dual-phase Ti-6Al-4V alloys: A discussion on the impact of Fe content. J. Alloys Compd. 2020, 858, 157708. [CrossRef]

85. Su, B.; Luo, L.; Wang, B.; Su, Y.; Wang, L.; Ritchie, R.O.; Guo, E.; Li, T.; Yang, H.; Huang, H.; et al. Annealed microstructure dependent corrosion behavior of Ti-6Al-3Nb-2Zr-1Mo alloy. J. Mater. Sci. Technol. 2021, 62, 234-248. [CrossRef]

86. Chen, X.; Shah, K.; Dong, S.; Peterson, L.; Callagon La Plante, E.; Sant, G. Elucidating the corrosion-related degradation mechanisms of a Ti-6Al-4V dental implant. Dent. Mater. 2020, 36, 431-441. [CrossRef]

87. Wang, J.L.; Liu, R.L.; Majumdar, T.; Mantri, S.A.; Ravi, V.A.; Banerjee, R.; Birbilis, N. A closer look at the in vitro electrochemical characterisation of titanium alloys for biomedical applications using in-situ methods. Acta Biomater. 2017, 54, 469-478. [CrossRef] 